\title{
Analisis Ekonomi Pemeliharaan Ayam Broiler dengan Pemberian Tepung Kulit Pisang Kepok Fermentasi + Feed Supplement
}

\section{(Economic Analysis of Administration of Fermented Banana Peel and Feed Supplement as Partial Substitution of Commercial Broiler Diet)}

\author{
Cut Aida Fitri, Zulfan, Syairazi \\ Program Studi Peternakan, Fakultas Pertanian, Universitas Syiah Kuala
}

\begin{abstract}
Abstrak: Tujuan penelitian ini adalah untuk mengetahui pengaruh substitusi sebagian ransum komersil periode finisher dengan tepung kulit pisang fermentasi + bungkil kelapa + feed supplement terhadap efisiensi ekonomis pemeliharaan ayam broiler. Penelitian dilakukan di Laboratorium Lapangan Peternakan (LLP), Program Studi Perternakan, Fakultas Pertanian, Universitas Syiah Kuala, tanggal 1 April-5 Mei 2016. Penelitian menggunakan 100 ekor anak ayam broiler (DOC) strain lohmann. Perlakuan yang dicobakan adalah pemberian tepung kulit pisang kepok fermentasi + bungkil kelapa + feed supplement, sebanyak $0 \%\left(\mathrm{P}_{1}\right), 2,5 \%+1,5 \%+1 \%$ $\left(\mathrm{P}_{2}\right), 5 \%+3 \%+1 \%\left(\mathrm{P}_{3}\right) .7,5 \%+4,5 \%+1 \%\left(\mathrm{P}_{4}\right)$, dan $10 \%+6 \%+1 \%\left(\mathrm{P}_{5}\right)$ Parameter yang diamati meliputi aspek teknis (berat badan akhir dan total konsumsi ransum) dan aspek ekonomis (penerimaan, biaya, Income over Feed Cost, dan total income). Hasil penelitian memperlihatkan bahwa substitusi ransum komersil dengan sebanyak-banyaknya $10 \%$ tepung kulit pisang kepok fermentasi $+6 \%$ bungkil kelapa $+1 \%$ feed supplement selama periode finisher tidak berpengaruh nyata $(\mathrm{P}>0.05)$ terhadap berat badan akhir dan total konsumsi ransum ayam broiler. Substitusi ransum komersil dengan tepung kulit pisang kepok fermentasi + bungkil kelapa + feed supplement selama periode finisher menurunkan biaya ransum dan menaikkan IOFC dan total income. Ransum komersil paling layak dan menguntungkan jika disubstitusi dengan 7,5\% tepung kulit pisang kepok fermentasi + $4,5 \%$ bungkil kelapa $+1 \%$ feed supplement selama periode finisher.
\end{abstract}

Kata Kunci: broiler, income, kulit pisang fermentasi

Abstract: The aim of present study was to analysis the efficiency of partial substitution of commercial broiler diet with fermented banana peel + coconut meal + feed supplement during finisher period. The study was conducted in Field Laboratory of Animal Husbandy Department, Faculty of Agriculture, Syiah Kuala University, April 1 until Mei 5, 2016. As many as 100 chicks, strain lohmann. The treatment was the provision of fermented banana peel + coconut meal + feed supplement, with the level of $0 \%\left(\mathrm{P}_{1}\right), 2,5 \%+1,5 \%+1 \%\left(\mathrm{P}_{2}\right), 5 \%+3 \%+1 \%\left(\mathrm{P}_{3}\right)$. $7,5 \%+4,5 \%+1 \%\left(\mathrm{P}_{4}\right)$, and $10 \%+6 \%+1 \%\left(\mathrm{P}_{5}\right)$, respectively. The parameters observed involved both production technical aspects (final body weight and total feed consumption) and economic aspects (revenue, cost, Income over Feed Cost, and total income) of raising broilers fed the commercial diets substituted partially by fermented banana peel + coconut meal + feed supplement. The results of study showed that administration of fermented banana peel up to $10 \%+$ coconut meal $6 \%+$ feed supplement $1 \%$ as partial substitution of commercial broiler finisher diet during finisher periode was not significant effect $(\mathrm{P}>0.05)$ on final body weight and feed consumption. Substituting commercial diet with fermented banana peel up to $10 \%+$ coconut meal $6 \%+$ feed supplement $1 \%$ reduced cost and increased IOFC as well as total income. It was suggested that the best level of substitution of finisher commercial diet was 7,5\% fermented banana peel $+4,5 \%$ coconut meal $+1 \%$ feed supplement.

Key words: broiler, income, fermentation, banana peel

\section{PENDAHULUAN}

Biaya pakan merupakan salah satu faktor yang memegang peranan penting dalam proses produksi ayam broiler. Hal ini dikarenakan biaya pakan merupakan biaya terbesar dalam produksi ayam broiler yang mencapai $70-80 \%$ dari total biaya produksi. Besarnya biaya pakan menuntut upaya untuk bisa memperoleh bahan pakan alternatif, murah, mudah didapat, dan kandungan nutrisi yang baik, salah satunya adalah kulit pisang.

Kulit pisang merupakan limbah dari buah pisang setelah dimanfaatkan isinya untuk makanan manusia. Limbah kulit tanaman ini banyak terdapat di daerah Aceh dengan harga sangat murah bahkan cuma-cuma. Padahal, kulit pisang masih mengandung zat gizi, seperti 
karbohidrat, air, Vitamin C, kalium, lutein, antioksidan, kalsium, Vitamin B, lemak, beragam Vitamin B kompleks di antaranya Vitamin B6, minyak nabati, serat, serotonin, dan lain-lain (Koni et al., 2013). Limbah kulit pisang ini dapat dimanfaatkan untuk pakan ternak (Kumalaningsih, 1993; Koni et al., 2006). Penggunaan tepung kulit pisang sebagai bahan substitusi sebagian ransum komersil untuk ternak dapat mengurangi harga per kilogram ransum komersil. Namun demikian, kadar protein ransum menjadi turun, sedangkan kadar serat kasarnya naik. Untuk itu, tepung kulit pisang perlu difermentasi terlebih dahulu. Selain itu diperlukan bahan pakan lain sebagai sumber protein, seperti bungkil kelapa.

Bungkil kelapa merupakan hasil sampingan dari penggilingan minyak kelapa. Bahan pakan ini cukup banyak terdapat di Aceh dan harganya pun murah. Bungkil kelapa masih mengandung protein cukup tinggi, yaitu sekitar 22\% (Chuzaemi et al., 1997), namun energinya rendah. Penambahan bungkil kelapa dapat menyeimbangkan kembali ratio energi-protein di dalam ransum komersil yang disubstitusi dengan tepung kulit pisang. Meskipun demikian, kandungan zat gizi lainnya diperkirakan juga akan menurun disebabkan nilai gizi tepung kulit pisang dan bungkil kelapa tidak sebaik ransum komersil.

Guna melengkapi zat-zat gizi lainnya, terutama vitamin, mineral, dan asam amino di dalam ransum substitusi maka perlu ditambahkan feed supplement. Feed supplement merupakan bahan makanan berupa campuran preparat vitamin, mineral, dan antibiotika guna melengkapi ransum (Sudaryani dan Santoso, 2003). Berdasarkan hal tersebut maka dilakukan penelitian untuk melihat kelayakan ekonomis pemeliharaan ayam broiler yang diberi ransum komersil dengan substitusi sebagian tepung kulit pisang kepok fermentasi + bungkil kelapa ditambah feed supplement. Tujuan penelitian ini adalah untuk melihat pengaruh penggunaan tepung kulit pisang kepok fermentasi + bungkil kelapa + feed supplement sebagai substitusi sebagian ransum komersil pada periode finisher terhadap efesiensi ekonomis pemeliharaan ayam broiler.

\section{MATERI DAN METODE}

\section{Tempat dan Waktu}

Penelitian ini dilakukan di Laboratorium Lapangan Peternakan (LLP), Program Studi Peternakan, Fakultas Pertanian, Univeritas Syiah Kuala, Banda Aceh tanggal 1 April sampai dengan 5 Mei 2016.

\section{Materi Penelitian} lohmann.

Penelitian ini menggunakan seratus ekor Day Old Chick (DOC) ayam broiler, strain

\section{Bahan dan Alat}

Bahan yang digunakan dalam penelitian ini terdiri dari ransum komersil broiler R511 dan R512 Bravo, kulit pisang kepok, ragi tape, bungkil kelapa, feed supplement (top mix), vaksin ND, vaksin gumboro, vitachick, vitastress, desinfektan, litter, koran bekas, kantung plastik, dan kapur. Peralatan yang digunakan meliputi kandang individual, tempat pakan, tempat minum, lampu pemanas, timbangan, dan peralatan penunjang kandang, serta peralatan pembuatan tepung kulit pisang fermentasi (nampan, kukusan, pisau, alat peniris, kompor, dan disc mill). 


\section{Ransum Perlakuan}

Penelitian ini menggunakan ransum dasar berupa ransum komersil berupa $R_{511}$ Bravo untuk umur 0-3 minggu (starter) dan $\mathrm{R}_{512}$ Bravo yang sebagian disubstitusi dengan tepung kulit pisang kepok fermentasi + bungkil kelapa + feed supplement untuk umur 3-5 minggu (finisher). Ransum perlakuan yang digunakan adalah sebagai berikut:

$\mathrm{P}_{1}$ : Ransum komersil broiler 512 Bravo 100\% + tepung kulit pisang kepok fermentasi $0 \%+$ bungkil kelapa $0 \%+$ feed supplement $0 \%$ (kontrol)

$\mathrm{P}_{2}$ : Ransum komersil broiler 512 Bravo $95,0 \%+$ tepung kulit pisang kepok fermentasi $2,5 \%$ + bungkil kelapa $1,5 \%+$ feed supplement $1 \%$

$\mathrm{P}_{3}$ : Ransum komersil broiler 512 Bravo 91,0\% + tepung kulit pisang kepok fermentasi $5,0 \%+$ bungkil kelapa $3,0 \%+$ feed supplement $1 \%$

$\mathrm{P}_{4}$ : Ransum komersil broiler 512 Bravo 87,0\% + tepung kulit pisang fermentasi 7,5\% + bungkil kelapa $4,5 \%+$ feed supplement $1 \%$

$\mathrm{P}_{5}$ : Ransum komersil broiler 512 Bravo 83,0\% + tepung kulit pisang fermentasi 10,0\% + bungkil kelapa $6,0 \%+$ feed supplement $1 \%$

Tabel 1. Susunan dan Kandungan Zat Gizi Ransum Penelitian

\begin{tabular}{|c|c|c|c|c|c|}
\hline \multirow[t]{2}{*}{ Bahan Pakan } & \multicolumn{5}{|c|}{$\begin{array}{c}\text { Ransum Komersil Broiler Disubstitusi dengan Tepung Kulit Pisang Kepok } \\
\text { Fermentasi + Bungkil Kelapa + Feed Supplement }\end{array}$} \\
\hline & $P_{1}$ & $\mathrm{P}_{2}$ & $\mathrm{P}_{3}$ & $\mathrm{P}_{4}$ & $\mathrm{P}_{5}$ \\
\hline 512 Bravo") & 100 & 95,0 & 91,0 & 87,0 & 83,0 \\
\hline $\begin{array}{l}\text { Tepung Kulit Pisang } \\
\text { Fermentas:**) }\end{array}$ & 0 & 2,5 & 5,0 & 7,5 & 10,0 \\
\hline Bungkil Kelapa ${ }^{* * * *}$ & 0 & 1,5 & 3,0 & 4,5 & 6,0 \\
\hline Feed Supplement & 0 & 1,0 & 1,0 & 1,0 & 1,0 \\
\hline Jumlah & 100 & 100 & 100 & 100 & 100 \\
\hline \multicolumn{6}{|c|}{ Kandungan Zat Gizi Berdasarkan Perhitungan } \\
\hline Protein $(\%)$ & $19,00-21,50$ & $18,97-21,34$ & $19,13-21,40$ & $19,29-21,46$ & $19,45-21,52$ \\
\hline Serat Kasar $(\%)(\max )$ & 5,00 & 5,39 & 5,85 & 6,28 & 6,73 \\
\hline Lemak Kasar (\%) (min) & 5,00 & 4,86 & 4,77 & 4,67 & 4,58 \\
\hline $\mathrm{Ca}(\%)(\min )$ & 0,90 & 1,05 & 1,20 & 1,36 & 1,52 \\
\hline $\mathrm{P}(\%)(\min )$ & 0,60 & 0,65 & 0,70 & 0,76 & 0,81 \\
\hline $\begin{array}{ll}\left.{ }^{*}\right) & \text { Kandungan zat } \\
& \text { lemak kasar 5\%, serat } \\
* * *) & \text { Kandungan zat gizi b }\end{array}$ & $\begin{array}{l}\text { zi berdasarkan } \\
\text { casar } 5 \%, \mathrm{Ca} 0,9 \\
\text { dasarkan Koni ( }\end{array}$ & $\begin{array}{l}\text { bel kemasan } \\
\text { dan P } 0,6 \% \text {. } \\
09 \text { ) }\end{array}$ & & & ar $19.0-21,5$ \\
\hline ***) Kandungan zat gizi & & & & & \\
\hline
\end{tabular}

\section{Rancangan Penelitian}

Rancangan penelitian yang digunakan adalah Rancangan Acak Kelompok (block randomized design) terdiri dari 5 perlakuan dan 4 kelompok. Setiap kelompok merupakan unit percobaan yang terdiri dari lima ekor ayam sehingga total ayam adalah seratus ekor. Perlakuan yang diberikan adalah penggunaan ransum komersil broiler 512 Bravo yang sebagian disubstitusi dengan tepung kulit pisang kepok fermentasi + bungkil kelapa + feed supplement dengan taraf berbeda.

Model matematika penelitian menurut Steel dan Torrie (1993) adalah sebagai berikut :

$Y_{i j}=\mu+\tau_{i}+\beta_{j}+\varepsilon_{i j}$

Keterangan:

$\mu=$ Rataan umum

$\tau_{i}=$ Pengaruh perlakuan ke- $i$

$\beta_{j}=$ Pengaruh kelompok ke- $j$ 
$\varepsilon_{i j}=$ Pengaruh galat perlakuan ke- $i$, kelompok ke- $j$

\section{Pembuatan Tepung Kulit Pisang Fermentasi}

Proses pembuatan tepung kulit pisang fermentasi dilakukan dengan prosedur sebagai berikut: (1) kulit pisang kepok dikumpulkan dari penjual pisang goreng, (2) dicuci, (3) dipotong kecil-kecil dengan ukuran $\pm 5 \mathrm{~cm}$, (4) dikukus selama \pm 25 menit untuk mematikan kuman pathogen, (5) diangin-anginkan, (6) dicampur ragi sebanyak $3 \mathrm{~g} / \mathrm{kg}$ kulit pisang, (7) dibungkus di dalam kantung plastik tidak padat agar jamur dapat tumbuh optimum selama empat hari, (8) disimpan pada suhu kamar selama 48 jam, (9) dikeringkan, dan (10) digiling hingga menjadi tepung.

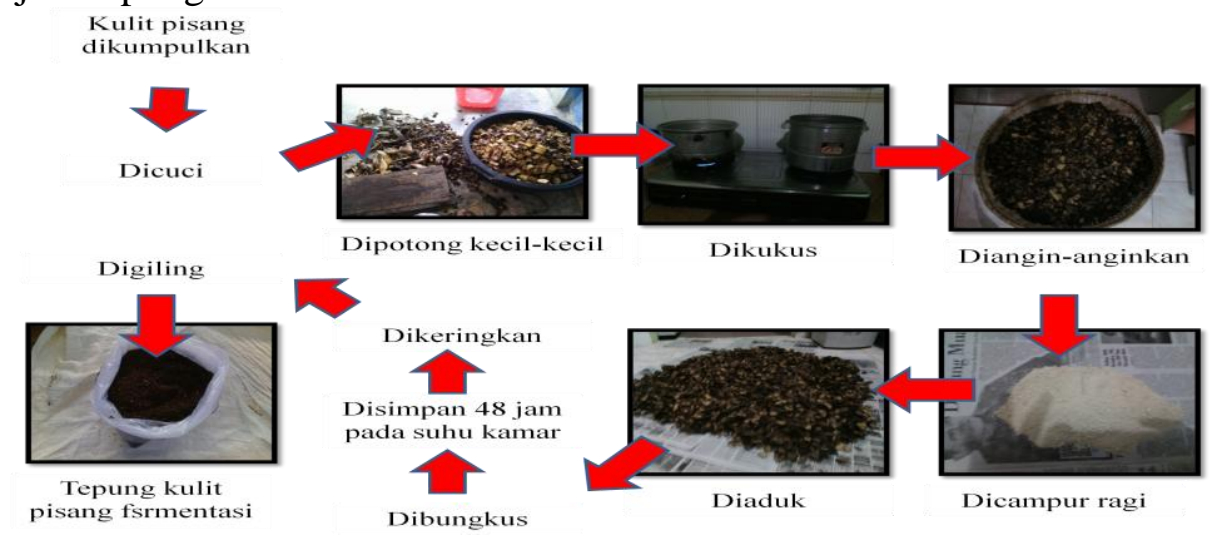

Gambar 1. Skema Proses Pembuatan Tepung Kulit Pisang Fermentasi

\section{Pelaksanaan Penelitian}

Penelitian ini dilakukan dalam tiga tahap, yaitu:

a. Tahap persiapan; terdiri dari persiapan kandang dan ransum. Persiapan kandang meliputi pembersihan kandang, sanitasi kandang (dalam kandang dan luar kandang), pencucian, penyemprotan desinfektan, persiapan tempat pakan dan tempat minum, pemasangan bola lampu pijar, dan penomoran kandang secara acak. Persiapan ransum meliputi persiapan bahan pakan, pembuatan tepung kulit pisang kepok fermentasi, dan penyusunan ransum perlakuan.

b. Tahap pemeliharaan; terdiri dari periode starter (0-3 minggu) dan grower/finisher (3-5 minggu). Selama periode 0-3 minggu, ayam dari semua perlakuan diberikan $100 \%$ ransum komersil $\mathrm{R}_{511}$. Selama periode 3-5 minggu, ayam dari perlakuan $\mathrm{P}_{1}$ diberikan $100 \%$ ransum komersil $\mathrm{R}_{512}$, sedangkan perlakuan $\mathrm{P}_{2}-\mathrm{P}_{5}$, diberikan ransum

komersil $\mathrm{R}_{512}$ yang disubstitusi dengan tepung kulit pisang kepok fermentasi + bungkil kelapa + feed supplement. Ransum diberikan ad libitum dengan pemberian dua kali sehari, yaitu pukul 08.00 dan 17.00 WIB. Vaksinasi ND dilakukan pada umur 3 hari melalui tetes mata dan diulangi pada umur 21 hari melalui suntikan intramuskuler. Vaksinasi gumboro dilakukan pada umur 12 hari melalui tetes mulut.

c. Tahap pengambilan data; dilakukan tiap-tiap minggu dari minggu pertama hingga minggu terakhir. Data yang diambil pada awal penelitian antara lain adalah harga dan banyak pemakaian desinfektan, kapur, dan DOC. Data yang diambil selama penelitian antara lain adalah harga dan banyak pemakaian litter, vitamin, vaksin, listrik, dan ransum. Data yang diambil pada akhir penelitian adalah berat badan akhir, total konsumsi ransum, dan harga jual ayam. Total ransum yang diberikan dan ransum sisa 
selama pemeliharaan 35 hari dihitung untuk mengetahui total konsumsi ransum yang dihabiskan. Harga jual ayam ditentukan berdasarkan harga jual yang berlaku di pasaran pada saat penelitian.

\section{Parameter Penelitian}

Parameter yang diukur dalam penelitian ini yaitu berat badan akhir, konsumsi ransum, penerimaan, total biaya, Income over feed cost (IOFC), dan total keuntungan.

\section{Analisa Data}

Data berat badan dan konsumsi ransum dianalisis dengan Analysis of Variance (ANOVA). Jika dari analisis tersebut didapatkan hasil yang berbeda nyata, maka dilanjutkan dengan uji Jarak Berganda Duncan (Steel dan Torrie, 1993). Data aspek ekonomi dianalisis dengan cara melihat kelayakan pemeliharaannya yang dihitung $\mathrm{R} / \mathrm{C}$ dan $\mathrm{B} / \mathrm{C}$ ratio (Sjahrial, 2008).

\section{HASIL DAN PEMBAHASAN}

\section{Berat Badan dan Konsumsi Ransum}

Dua parameter produksi penting yang terkait dengan perhitungan analisis ekonomis pemeliharaan ayam broiler adalah berat badan akhir dan total konsumsi ransum yang dihabiskan selama pemeliharaan. Berat badan akhir dan total konsumsi ransum ayam broiler yang diberi ransum komersil yang disubstitusi dengan tepung kulit pisang kepok fermentasi + bungkil kelapa + feed supplement selama periode finisher (4-5 minggu) diperlihatkan pada Tabel 2.

Tabel 2. Berat Badan Akhir dan Total Konsumsi Ransum Ayam Broiler yang Diberi Ransum Komersil yang Disubstitusi Tepung Kulit Pisang Kepok Fermentasi + Bungkil Kelapa + Feed Supplement selama Periode Finisher

\begin{tabular}{|c|c|c|c|c|c|}
\hline \multirow[b]{2}{*}{ Parameter } & \multicolumn{5}{|c|}{$\begin{array}{ll}\text { Ransum } & \text { Komersil + Tepung Kulit Pisang Fermentasi + } \\
& \text { Bungkil Kelapa + Feed Supplement }\end{array}$} \\
\hline & $\begin{array}{c}100 \% \mathrm{RK}+0 \% \\
\mathrm{TKP}+0 \% \\
\mathrm{BK}+0 \% \mathrm{FS} \\
\left(\mathrm{P}_{1}\right)\end{array}$ & $\begin{array}{c}95 \% \mathrm{RK}+2.5 \% \\
\mathrm{TKP}+1.5 \% \\
\mathrm{BK}+1 \% \mathrm{FS} \\
\left(\mathrm{P}_{2}\right)\end{array}$ & $\begin{array}{c}91 \% \mathrm{RK}+5 \% \\
\mathrm{TKP}+3 \% \\
\mathrm{BK}+1 \% \mathrm{FS} \\
\left(\mathrm{P}_{3}\right)\end{array}$ & $\begin{array}{c}87 \% \mathrm{RK}+7.5 \% \\
\mathrm{TKP}+4.5 \% \\
\mathrm{BK}+1 \% \mathrm{FS} \\
\left(\mathrm{P}_{4}\right) \\
\end{array}$ & $\begin{array}{c}83 \% \mathrm{RK}+10 \% \\
\mathrm{TKP}+6 \% \\
\mathrm{BK}+1 \% \mathrm{FS} \\
\left(\mathrm{P}_{5}\right)\end{array}$ \\
\hline Berat badan & $1.906,48$ & $1.846,75$ & $1.886,89$ & $1.912,98$ & $1.842,83$ \\
\hline 5 minggu (g/ekor) & $\pm 199,10$ & $\pm 183,02$ & $\pm 163,49$ & $\pm 214,16$ & $\pm 218,22$ \\
\hline Total konsumsi & $3.466,75$ & $3.419,09$ & $3.428,55$ & $3.463,08$ & $3.424,57$ \\
\hline ransum (g/ekor) & $\pm 197,05$ & $\pm 177,79$ & $\pm 281,48$ & $\pm 192,48$ & $\pm 316,15$ \\
\hline
\end{tabular}

$\mathrm{RK}=$ Ransum komersil broiler, TKP= Tepung kulit pisang fermentasi, $\mathrm{BK}=$ Bungkil kelapa, $\mathrm{FS}=$ Feed supplement

Hasil sidik ragam memperlihatkan bahwa penggunaan tepung kulit pisang kepok fermentasi + bungkil kelapa + feed supplement sebagai substitusi sebagian ransum komersil selama periode finisher tidak berpengaruh nyata $(\mathrm{P}>0,05)$ terhadap berat badan akhir ayam broiler umur lima minggu. Ayam-ayam broiler yang diberi ransum komersil yang disubstitusi dengan sebanyak-banyaknya $10 \%$ tepung kulit pisang kepok fermentasi $+6 \%$ bungkil kelapa $+1 \%$ feed supplement $\left(\mathrm{P}_{2}-\mathrm{P}_{5}\right)$ memiliki berat badan akhir yang tidak jauh berbeda dengan ayam broiler yang diberikan seluruhnya ransum komersil $\left(\mathrm{P}_{1}\right)$.

Hasil penelitian ini menunjukkan bahwa tepung kulit pisang kepok fermentasi dapat digunakan sampai 10\% untuk mensubstitusi ransum komersil selama periode finisher dengan 
penambahan $6 \%$ bungkil kelapa ditambah $1 \%$ feed supplement tanpa menurunkan secara nyata bobot badan akhir ayam broiler. Hasil penelitian ini sesuai dengan Koni (2013), penggunaan tepung kulit pisang kepok fermentasi terbatas hingga 10\% dalam ransum ayam pedaging, jika digunakan lebih dari 10\% maka dapat menurunkan bobot badan. Berdasarkan Budiansyah (2010), protein kasar bahan pakan hasil fermentasi sebagian terdiri dari fraksi asam nukleat yang berasal dari sel-sel mikroba, protein tersebut sulit dicerna oleh saluran pencernaan unggas sehingga ketersediaan protein untuk pertumbuhan berkurang.

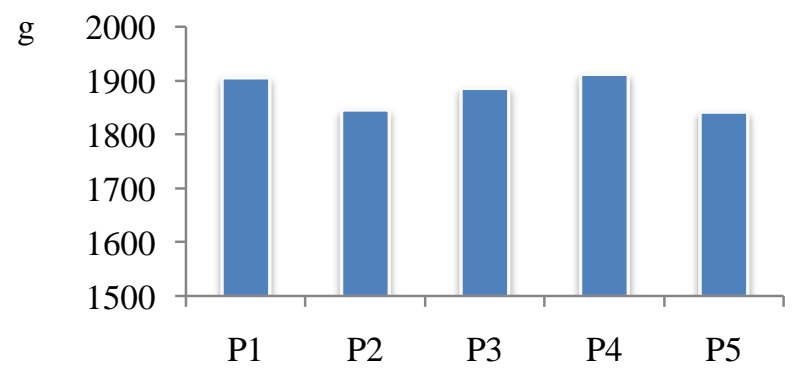

Gambar 2. Berat Badan Ayam Broiler pada Akhir Minggu ke-5 dari Semua Perlakuan

Tingkat energi metabolis berhubungan erat dengan kecernaan dan penyerapan zat-zat makanan. Kandungan serat kasar yang tinggi dalam kulit pisang akan menurunkan energi metabolis pakan, disebabkan terjadinya penurunan kecernaan bahan, sehingga mengakibatkan penurunan penyerapan zat-zat makanan (Bahri dan Budi, 2008). Hal ini sejalan dengan McDonald et al. (1994), energi metabolisme ditentukan oleh kandungan dan keseimbangan zat makanan dalam bahan dan serat kasar merupakan faktor utama yang menentukan energi metabolisme.

Hasil sidik ragam memperlihatkan bahwa pemberian ransum komersil yang sebagian disubstistusi dengan tepung kulit pisang fermentasi + bungkil kelapa + feed supplement selama periode finisher tidak berpengaruh nyata $(\mathrm{P}>0,05)$ terhadap total konsumsi ransum ayam broiler selama pemeliharaan lima minggu. Total konsumsi ransum ayam broiler selama lima minggu dari semua perlakuan tidak jauh berbeda. Hasil ini memperlihatkan bahwa penggunaan tepung kulit pisang kepok fermentasi sampai $10 \%$ ditambah bungkil kelapa sampai $6 \%$ di dalam ransum finisher tidak berefek terhadap penurunan konsumsi ransum ayam broiler. Ayam broiler yang diberikan ransum komersil yang disubstitusi dengan tepung kulit pisang kepok fermentasi sampai $10 \%$ + bungkil kelapa sampai $6 \%$ selama periode finisher tidak memperlihatkan penolakan terhadap pakan substitusi tersebut. Tidak diketahui secara pasti apakah tepung kulit pisang kepok fermentasi memiliki palatabilitas yang kurang disukai atau tidak, kenyataannya ayam broiler tetap mengkonsumsi dengan baik ransum-ransum substitusi tersebut. 


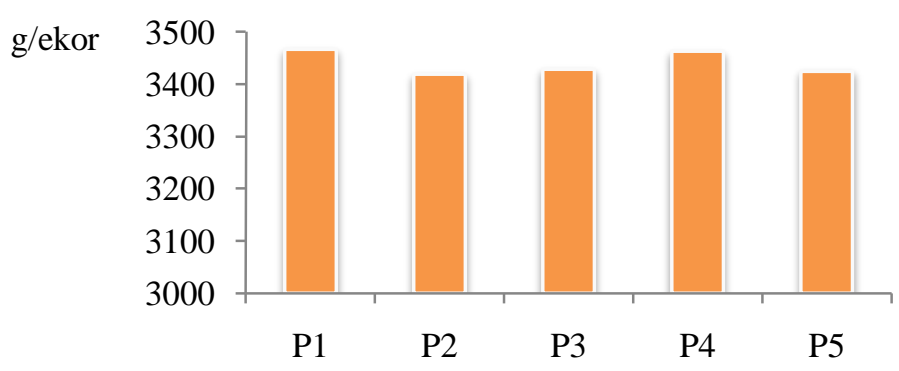

Gambar 3. Total Konsumsi Ransum Ayam Broiler 0-5 minggu dari Semua Perlakuan

Menurut Rasyaf (2008), palatabilitas merupakan salah satu faktor yang mempengaruhi konsumsi ransum. Namun demikian, berdasarkan Anggorodi (1985), palatabilitas bukanlah hal utama bagi ayam broiler, melainkan kebutuhan energinya. Jika energinya belum terpenuhi maka ayam akan terus makan. Ayam-ayam broiler selama periode finisher membutuhkan energi yang tinggi sehingga konsumsi ransumnya juga tinggi. Kemungkinan, ayam broiler dalam penelitian ini selama periode finisher lebih mengutamakan kebutuhan energinya daripada palatablitas. Hal ini terlihat dari capaian berat badan akhir ayam broiler yang diberikan ransum komersil dengan substitusi tepung kulit pisang fermentasi + bungkil kelapa + feed supplement $\left(\mathrm{P}_{2}-\mathrm{P}_{5}\right)$ tidak jauh berbeda dibandingkan dengan ayam yang mendapatkan $100 \%$ ransum komersil $\left(\mathrm{P}_{1}\right)$.

\section{Penerimaan}

Penerimaan total merupakan hasil kali produksi total dengan harganya (Hanafie, 2010). Berdasarkan hasil analisis penerimaan terlihat bahwa pemeliharaan ayam broiler yang diberikan ransum komersil dengan substitusi tepung kulit pisang kepok fermentasi + bungkil kelapa + feed supplement selama periode finisher memiliki penerimaan sedikit lebih rendah dibandingkan dengan pemeliharaan ayam broiler yang diberi $100 \%$ ransum komersil (kecuali $\left.\mathrm{P}_{4}\right)$. Ini dikarenakan ayam broiler dari perlakuan $100 \%$ ransum komersil $\left(\mathrm{P}_{1}\right)$ memiliki berat badan yang sedikit lebih tinggi dibandingkan dengan ayam broiler dari perlakuan substitusi tepung kulit pisang kepok fermentasi + bungkil kelapa + feed supplement (kecuali $\mathrm{P}_{4}$ ), sedangkan harga satuan penjualannya adalah sama untuk semua ayam broiler. Penerimaan belum dapat digunakan untuk menggambarkan seberapa ekonomis pemeliharaan ayam broiler. Oleh karena itu perlu pula dihitung biaya-biaya, yang diperlihatkan pada Tabel 3 .

Tabel 3. Penerimaan dari Pemeliharaan Ayam Broiler pada Umur Lima minggu yang Diberi Ransum Komersil dengan Substitusi Tepung Kulit Pisang Kepok Fermentasi + Bungkil Kelapa + Feed Supplement (Rp/ekor)

\begin{tabular}{|c|c|c|c|c|c|}
\hline \multirow[b]{2}{*}{ Jenis Penerimaan } & \multicolumn{5}{|c|}{$\begin{array}{c}\text { Ransum } \begin{array}{c}\text { Komersil +Tepung Kulit Pisang Kepok Fermentasi + } \\
\text { Bungkil Kelapa }+ \text { Feed Supplement }\end{array} \\
\end{array}$} \\
\hline & $\begin{array}{c}100 \% \mathrm{RK}+0 \% \\
\mathrm{TKP}+0 \% \\
\mathrm{BK}+0 \% \mathrm{FS} \\
\left(\mathrm{P}_{1}\right)\end{array}$ & $\begin{array}{c}95 \% \mathrm{RK}+2.5 \% \\
\mathrm{TKP}+1.5 \% \\
\mathrm{BK}+1 \% \mathrm{FS} \\
\left(\mathrm{P}_{2}\right)\end{array}$ & $\begin{array}{c}91 \% \mathrm{RK}+5 \% \\
\mathrm{TKP}+3 \% \\
\mathrm{BK}+1 \% \mathrm{FS} \\
\left(\mathrm{P}_{3}\right)\end{array}$ & $\begin{array}{c}87 \% \mathrm{RK}+7.5 \% \\
\mathrm{TKP}+4.5 \% \\
\mathrm{BK}+1 \% \mathrm{FS} \\
\left(\mathrm{P}_{4}\right)\end{array}$ & $\begin{array}{c}83 \% \mathrm{RK}+10 \% \\
\mathrm{TKP}+6 \% \\
\mathrm{BK}+1 \% \mathrm{FS} \\
\left(\mathrm{P}_{5}\right)\end{array}$ \\
\hline Penjualan Ayam & $40.036,13$ & $38.781,75$ & $39.624,64$ & $40.172,48$ & $38.699,33$ \\
\hline Lain-lain & 0,00 & 0,00 & 0,00 & 0,00 & 0,00 \\
\hline Total & $40.036,13$ & $38.781,75$ & $39.624,64$ & $40.172,48$ & $38.699,33$ \\
\hline
\end{tabular}




\section{Biaya-Biaya}

Biaya produksi adalah biaya yang dikeluarkan sejak dari pembukaan kegiatan suatu usaha atau proyek sampai dengan usaha tersebut menghasilkan (Hermanto, 1995). Hasil analisis biaya memperlihatkan bahwa substitusi sebagian ransum komersil dengan tepung kulit pisang kepok fermentasi + bungkil kelapa + feed supplement $\left(\mathrm{P}_{2}-\mathrm{P}_{5}\right)$ selama periode finisher menurunkan total biaya (total cost) pemeliharaan ayam broiler. Semakin banyak tepung kulit pisang kepok fermentasi + bungkil kelapa digunakan semakin menurunkan total biaya. Penurunan total biaya ini dikarenakan terjadinya penurunan biaya variabel (variable cost). Biaya variabel yang berkurang adalah biaya ransum (diet cost). Ini dikarenakan harga per kilogram ransum (feed price) menjadi menurun sebagai akibat dari penggunaan tepung kulit pisang kepok fermentasi + bungkil kelapa. Ini berarti bahwa penggunaan tepung kulit pisang fermentasi + bungkil kelapa + feed supplement sebagai substitusi ransum komersil dapat menurunkan biaya pemeliharaan broiler.

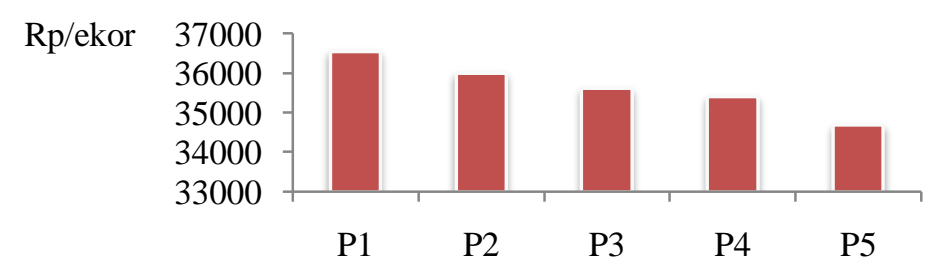

Gambar 4. Total Biaya Pemeliharaan Ayam Broiler Selama Lima Minggu dari Semua Perlakuan

Tabel 4. Biaya Pemeliharaan Ayam Broiler yang Diberi Ransum Komersil dengan Substitusi Tepung Kulit Pisang Kepok Fermentasi + Bungkil Kelapa + Feed Supplement

\begin{tabular}{|c|c|c|c|c|c|}
\hline \multirow[b]{2}{*}{ Biaya (cost) } & \multicolumn{5}{|c|}{$\begin{array}{l}\text { Tepung Kulit Pisang Ferm } \\
\text { apa }+ \text { Feed Supplement }\end{array}$} \\
\hline & $\begin{array}{c}100 \% \mathrm{RK}+0 \% \\
\mathrm{TKP}+0 \% \\
\mathrm{BK}+0 \% \mathrm{FS} \\
\left(\mathrm{P}_{1}\right)\end{array}$ & $\begin{array}{c}95 \% \mathrm{RK}+2.5 \% \\
\mathrm{TKP}+1.5 \% \\
\mathrm{BK}+1 \% \mathrm{FS} \\
\left(\mathrm{P}_{2}\right)\end{array}$ & $\begin{array}{c}91 \% \mathrm{RK}+5 \% \\
\mathrm{TKP}+3 \% \\
\mathrm{BK}+1 \% \mathrm{FS} \\
\left(\mathrm{P}_{3}\right) \\
\end{array}$ & $\begin{array}{c}87 \% \mathrm{RK}+7.5 \% \\
\mathrm{TKP}+4.5 \% \\
\mathrm{BK}+1 \% \mathrm{FS} \\
\left(\mathrm{P}_{4}\right) \\
\end{array}$ & $\begin{array}{c}83 \% \mathrm{RK}+10 \% \\
\mathrm{TKP}+6 \% \\
\mathrm{BK}+1 \% \mathrm{FS} \\
\left(\mathrm{P}_{5}\right) \\
\end{array}$ \\
\hline \multicolumn{6}{|c|}{ Biaya variabel (variable cost, $\mathrm{BV}$ ) (Rp/ekor) } \\
\hline BV Ransum & $26.428,37$ & $25.874,79$ & $25.496,13$ & $25.290,65$ & $24.569,31$ \\
\hline BV lain & $8.571,33$ & $8.571,33$ & $8.571,33$ & $8.571,33$ & $8.571,33$ \\
\hline Total BV & $34.999,70$ & $34.446,12$ & $34.067,46$ & $33.861,98$ & $33.140,64$ \\
\hline $\begin{array}{l}\text { Biaya tetap } \\
\text { (fixed cost) } \\
\text { Total Biaya }\end{array}$ & $1.553,21$ & $1.553,21$ & $1.553,21$ & $1.553,21$ & $1.553,21$ \\
\hline (total cost) & $36.552,91$ & $35.999,33$ & $35.620,67$ & $35.415,19$ & $34.693,85$ \\
\hline
\end{tabular}

\section{IOFC dan Total Income}

Salah satu cara melihat ekonomis pemeliharaan ayam broiler adalah menghitung Income Over Feed Cost (IOFC)-nya. Hal ini dikarenakan ransum merupakan biaya paling besar dalam pemeliharaan ayam broiler, yaitu sekitar $60-70 \%$ dari total biaya produksi (Rasyaf, 2008). Dalam penelitian ini, biaya ransum paling tinggi terdapat pada pemeliharaan ayam broiler dengan pemberian $100 \%$ ransum komersil $\left(\mathrm{P}_{1}\right)$ yang mencapai $72,30 \%$, sedangkan paling rendah terdapat pada pemeliharaan ayam broiler dengan pemberian $10 \%$ tepung kulit pisang fermentasi + bungkil kelapa $+1 \%$ feed supplement sebagai substitusi ransum komersil $\left(\mathrm{P}_{5}\right)$, yaitu $70,82 \%$ dari total biaya produksi. Dalam penelitian ini, semua 
komponen biaya adalah sama besar untuk semua perlakuan, kecuali biaya ransum. Nilai IOFC dan total income diperlihatkan pada Tabel 5.

Dari tabel dapat dilihat bahwa besarnya IOFC antar perlakuan adalah bervariasi. Substitusi tepung kulit pisang kepok fermentasi + bungkil kelapa + feed supplement (kecuali $\mathrm{P}_{2}$ ) selama periode periode finisher umumnya menghasilkan IOFC lebih tinggi dibandingkan dengan tanpa substitusi bahan pakan tersebut $\left(\mathrm{P}_{1}\right)$. Hal ini dikarenakan meskipun penerimaan sedikit berkurang (kecuali $\mathrm{P}_{4}$ ), ayam-ayam dari perlakuan ransum substitusi memiliki biaya ransum lebih rendah dari pada ayam-ayam dari perlakuan $100 \%$ ransum komersil $\left(\mathrm{P}_{1}\right)$. Substitusi bahan-bahan pakan tersebut ke dalam ransum komersil sebanyak 7,5\% tepung kulit pisang kepok fermentasi $+4,5 \%$ bungkil kelapa $+1 \%$ feed supplement $\left(\mathrm{P}_{4}\right)$ selama periode finisher menghasilkan IOFC paling tinggi di antara semua perlakuan. Hal ini dikarenakan ayam-ayam dari perlakuan tersebut memiliki penerimaan paling tinggi dan biaya ransum paling rendah (kecuali dengan $\mathrm{P}_{5}$ ).

Tabel 5. $\quad$ IOFC dan Total Income Pemelihaaraan Ayam Broiler Umur Lima Minggu yang Diberi Ransum Komersil dengan Substitusi Tepung Kulit Pisang Kepok Fermentasi + Bungkil Kelapa + Feed Supplement

\begin{tabular}{|c|c|c|c|c|c|}
\hline \multirow[b]{2}{*}{ Keuntungan $^{1)}$} & \multicolumn{5}{|c|}{$\begin{array}{cl}\text { Ransum } & \text { Komersil + Tepung Kulit Pisang Fermentasi + } \\
& \text { Bungkil Kelapa + Feed Supplement }\end{array}$} \\
\hline & $\begin{array}{c}100 \% \mathrm{RK}+0 \% \\
\mathrm{TKP}+0 \% \\
\mathrm{BK}+0 \% \mathrm{FS} \\
\left(\mathrm{P}_{1}\right)\end{array}$ & $\begin{array}{c}95 \% \mathrm{RK}+2.5 \% \\
\mathrm{TKP}+1.5 \% \\
\mathrm{BK}+1 \% \mathrm{FS} \\
\left(\mathrm{P}_{2}\right)\end{array}$ & $\begin{array}{c}91 \% \mathrm{RK}+5 \% \\
\mathrm{TKP}+3 \% \\
\mathrm{BK}+1 \% \mathrm{FS} \\
\left(\mathrm{P}_{3}\right)\end{array}$ & $\begin{array}{c}87 \% \mathrm{RK}+7.5 \% \\
\mathrm{TKP}+4.5 \% \\
\mathrm{BK}+1 \% \mathrm{FS} \\
\left(\mathrm{P}_{4}\right) \\
\end{array}$ & $\begin{array}{c}83 \% \mathrm{RK}+10 \% \\
\mathrm{TKP}+6 \% \\
\mathrm{BK}+1 \% \mathrm{FS} \\
\left(\mathrm{P}_{5}\right)\end{array}$ \\
\hline IOFC & $13.607,76$ & $12.906,96$ & $14.128,51$ & $14.881,83$ & $14.130,02$ \\
\hline Total Income & $3.483,22$ & $2.782,42$ & $4.003,97$ & $4.757,29$ & $4.005,48$ \\
\hline
\end{tabular}

Nilai IOFC belum menggambarkan keuntungan yang sebenarnya, karena belum memasukkan komponen biaya lainnya. Oleh karena itu, total keuntungan (total income) perlu dihitung. Keuntungan dapat dicapai jika jumlah penerimaan yang diperoleh dari hasil usaha lebih besar daripada jumlah pengeluarannya (Soekartawi, 2002). .Dari tabel dapat dilihat bahwa total income dalam penelitian ini memiliki pola yang sama dengan IOFC dikarenakan tidak adanya perbedaan komponen biaya lainnya di antara perlakuan.

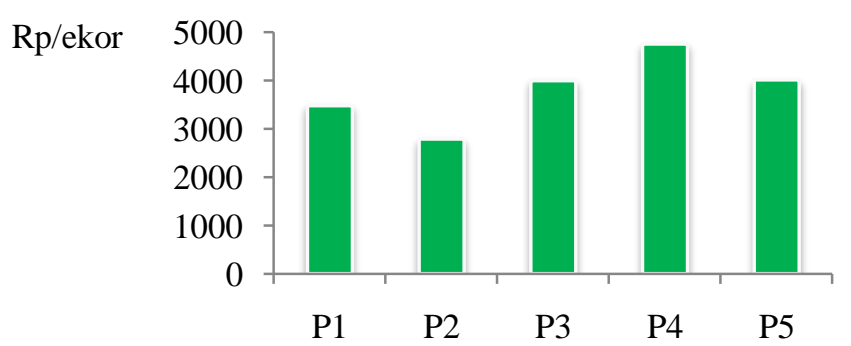

Gambar 5. Total Income Pemeliharaan Ayam Broiler Selama Lima Minggu dari Semua Perlakuan

Semua perlakuan memberikan keuntungan di mana tingkat keuntungan paling tinggi dicapai pada ayam-ayam yang dipelihara dengan pemberian ransum komersil yang disubtitusi dengan $7,5 \%$ tepung kulit pisang kepok fermentasi $+4,5 \%$ bungkil kelapa $+1 \%$ feed supplement $\left(\mathrm{P}_{4}\right)$ periode finisher. Substitusi sampai $10 \%$ tepung kulit pisang kepok fermentasi $+6 \%$ bungkil kelapa $+1 \%$ feed supplement $\left(\mathrm{P}_{5}\right)$ periode finisher pun masih menghasilkan total income yang lebih tinggi dibandingkan dengan penggunaan $100 \%$ ransum 
komersil $\left(\mathrm{P}_{1}\right)$. Ini dikarenakan meskipun umumnya ransum-ransum substitusi memberikan penerimaan yang sedikit berkurang, total cost menurun cukup besar sebagai akibat dari turunnya variable cost dari pemeliharaan ayam-ayam yang diberi ransum substitusi tersebut.

\section{Kelayakan Ransum}

Cara lain mengetahui apakah suatu ransum layak dan menguntungkan adalah dengan melihat $\mathrm{R} / \mathrm{C}$ dan $\mathrm{B} / \mathrm{C}$ ratio dalam pemeliharaan ayam tersebut. Analisis ekonomis pemeliharaan ayam-ayam yang dilakukan dalam penelitian ini dari semua perlakuan memperlihatkan $\mathrm{R} / \mathrm{C}$ ratio $>1$ dan $\mathrm{B} / \mathrm{C}$ ratio $>0$. Ini berarti penggunan sebanyak-banyaknya $10 \%$ tepung kulit pisang kepok fermentasi $+6 \%$ bungkil kelapa $+1 \%$ feed supplement $\left(\mathrm{P}_{5}\right)$ selama periode finisher sebagai substitusi sebagian ransum komersil layak dan menguntungkan dilakukan dalam pemeliharaan ayam broiler. Sebagaimana yang dikatakan oleh Sjahrial (2008), jika $\mathrm{R} / \mathrm{C}$ ratio > 1 dan $\mathrm{B} / \mathrm{C}$ ratio > 0 berarti layak usaha dan menguntungkan.

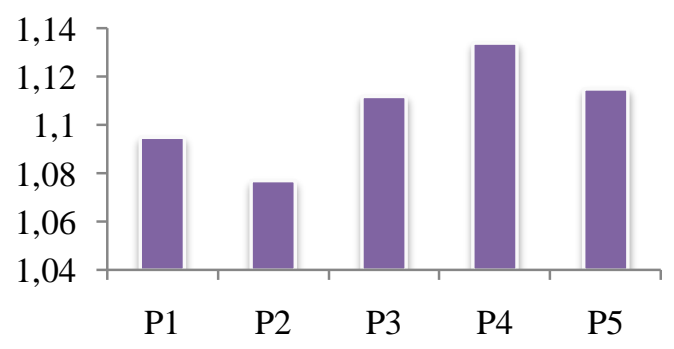

Gambar 6. R/C Ratio Pemeliharaan Ayam Broiler

Selama Lima Minggu dari Semua Perlakuan

Tabel 6. $\quad$ IOFC dan Total Income Pemelihaaraan Ayam Broiler Umur Lima Minggu yang Diberi Ransum Komersil dengan Substitusi Tepung Kulit Pisang Kepok Fermentasi + Bungkil Kelapa + Feed Supplement

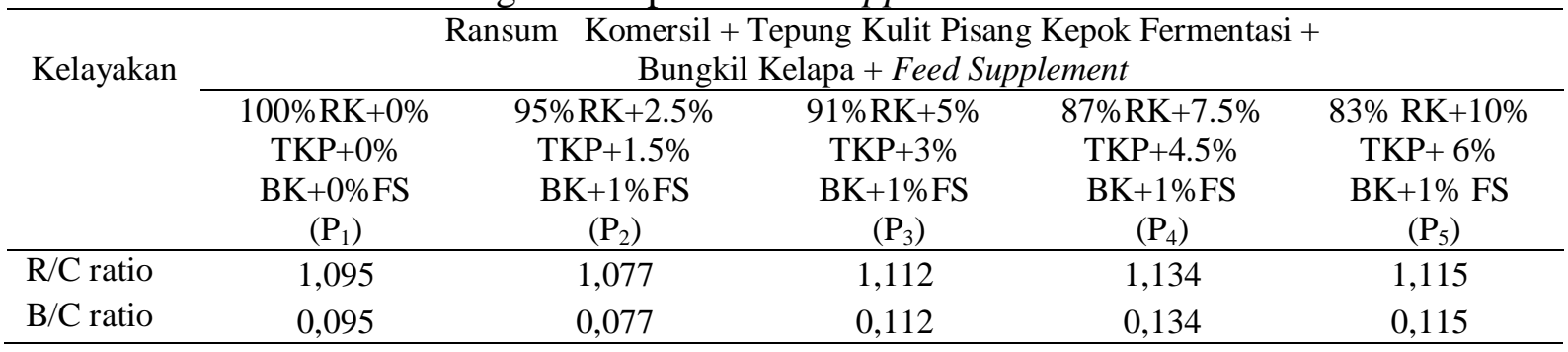

Dari tabel dapat dilihat bahwa $\mathrm{R} / \mathrm{C}$ dan $\mathrm{B} / \mathrm{C}$ ratio tertinggi terdapat pada pemeliharaan ayam-ayam broiler yang diberi ransum komersil dengan substitusi 7,5\% tepung kulit pisang kepok fermentasi $+4,5 \%$ bungkil kelapa $+1 \%$ feed supplement $\left(\mathrm{P}_{4}\right)$. Sedangkan $\mathrm{R} / \mathrm{C}$ dan $\mathrm{B} / \mathrm{C}$ ratio terendah terdapat pada pemeliharaan ayam-ayam broiler yang diberi $100 \%$ ransum komersil $\left(\mathrm{P}_{1}\right)$. Ini berarti bahwa penggunaan 7,5\% tepung kulit pisang kepok fermentasi + $4,5 \%$ bungkil kelapa $+1 \%$ feed supplement sangat layak dan menguntungkan dilakukan untuk mensubstitusi ransum komersil selama periode finisher pemeliharaan ayam broiler. 


\section{KESIMPULAN DAN SARAN}

\section{Kesimpulan}

Berdasarkan hasil penelitian yang telah dilakukan dapat disimpulkan bahwa:

1. Tepung kulit pisang kepok fermentasi dapat digunakan sampai $10 \%$ ditambah bungkil kelapa $6 \%$ dan feed supplement $1 \%$ untuk mensubstitusi sebagian penggunaan ransum komersil selama periode finisher tanpa berpengaruh nyata terhadap berat badan akhir dan total konsumsi ransum ayam broiler.

2. Substitusi ransum komersil dengan tepung kulit pisang kepok fermentasi + bungkil kelapa + feed supplement selama periode finisher menurunkan biaya ransum dan menaikkan Income Over Feed Cost (IOFC) dan total income dalam pemeliharaan ayam broiler.

3. Ransum komersil paling layak dan menguntungkan jika disubstitusi dengan 7,5\% tepung kulit pisang kepok fermentasi $+4,5 \%$ bungkil kelapa $+1 \%$ feed supplement $1 \%$ selama periode finisher pemeliharaan ayam broiler.

\section{Saran}

Berdasarkan hasil penelitian yang telah dilakukan disarankan :

1. Dalam pemeliharaan ayam broiler, penggunaan ransum komersil sebaiknya disubstitusi sebanyak 7,5\% tepung kulit pisang kepok fermentasi $+4,5 \%$ bungkil kelapa $+1 \%$ feed supplement selama periode finisher karena dapat menurunkan biaya ransum dan meningkatkan income.

2. Dilakukan penelitian lebih lanjut tentang penggunaan tepung kulit pisang di dalam ransum unggas lainnya, seperti itik, ayam arab, dan ayam buras.

\section{DAFTAR PUSTAKA}

Chuzaemi, S., Hermanto, Soebarinoto, dan H. Sudarwati. 1997. Evaluasi Protein Pakan Ruminansia Melalui Pendekatan Sintesis Protein Mikrobial di dalam Rumen. Evaluasi Kandungan RDP dan UDP pada Beberapa Jenis Hijauan Segar, Limbah Pertanian dan Konsentrat. Jurnal Penelitian Ilmu-Ilmu Hayati (Life Science) 9: 77-89.

Hanafie, R. 2010. Pengantar Ekonomi Pertanian. Ed. ke-1. CV. Andi Offset, Yogyakarta.

Hartadi, H., S. Reksohadiprodjo, S. Lebdosukojo, dan A. D. Tillman. 1980. Tabel-Tabel dari Komposisi Bahan Makanan Ternak untuk Indonesia (Tables of Feed Composition for Indonesia). The International Feedstuff Institute. Utah Agricultural Experiment Station. Utah State University, Logan, Utah.

Hermanto, F. 1995. Usahatani. PT. Penebar Swadaya, Jakarta.

Koni, T. N. I., A. Paga, dan T.A. Foenay. 2006. Substitusi Jagung dengan Campuran Kulit Pisang dan Ampas Kelapa dalam Ransum Ayam pedaging. Kupang. Laporan Hasil Penelitian Politani.

Koni, T.N.I. 2009. Pemanfaatan Tepung Kulit Pisang Hasil Fermentasi dengan Jamur Tempe (Rhyzopus oligosporus) dalam Ransum terhadap Pertumbuhan Broiler. Thesis S2 Universitas Nusa Cendana, Kupang.

2013. Pengaruh pemanfaatan kulit pisang yang difermentasi terhadap karkas broiler. JITV 18 (2): 153-157.

Koni, T. N. I., J. B. Therik, dan P. R. Kale. 2013. Pemanfaatan kulit pisang hasil fermentasi Ryzopus oligosporus dalam ransum terhadap pertumbuhan ayam pedaging. Jurnal Veteriner Vol. 14 No. 3: 365-370. 
Kumalaningsih, S. 1993. Sistem Penanganan dan Pengolahan Pisang Segar Modern. Sekolah Tinggi Pertanian Tribhuana, Malang.

Sjahrial, D. 2008. Kumpulan Pembahasan Soal-Soal Manajemen Keuangan. Ed. ke-1. Mitra Wacana Media, Jakarta.

Soekartawi, 2002. Prinsip Dasar Ekonomi Pertanian. PT. Raja Grafindo Persada, Jakarta.

Steel, R. G. D. dan J. H. Torrie. 1993. Prinsip dan Prosedur Statistika. Terjemahan oleh B. Sumantri. Cet. ke-2. PT. Gramedia, Jakarta.

Sudaryani, T. dan H. Santosa, 2003. Pembibitan Ayam Ras. Cet. ke-7. Penebar Swadaya, Jakarta.

\section{UCAPAN TERIMAKASIH}

Penulis menyampaikan terima kasih yang sebesar-besarnya kepada Syafriadi, Rismanda Sari, dan Yeyen Safitri atas kerjasamanya yang baik selama penelitian serta semua pihak yang turut membantu dalam penelitian ini. 